
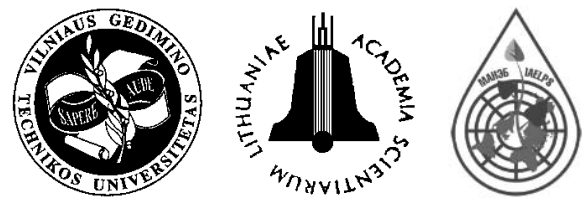

18(4): 306-311

\title{
EXPERIMENTAL ANALYSIS OF IRON IMPACT ON HEAVY METAL (COPPER) MIGRATION IN THE SOIL
}

\author{
Vaidotas Vaišis ${ }^{1}$, Lidija Šuksta ${ }^{2}$ \\ Dept of Environmental Protection, Vilnius Gediminas Technical University, \\ Sauletekio al. 11, LT-10223 Vilnius, Lithuania \\ E-mails: ${ }^{1}$ vaidotas.vaisis@vgtu.lt; ${ }^{2}$ aak@vgtu.lt \\ Submitted 7 Jun. 2007; accepted 7 Dec. 2009
}

\begin{abstract}
The paper focusses on analysis of the impact of iron particles on heavy metals migration in the soil within the northern area of Klaipeda city. The city has been chosen due to its function as a transit harbour locating 19 big companies related to the sea business and cargo services. Like every ecosystem, the soil is characterized by accumulating different substances with no exclusion of contaminants. For the analysis of iron impact on heavy metals migration, an experimental stand with six fixed columns was constructed. Copper salt solution was passed through the columns on quartz sand with iron filings (1.5 and 10\%) in it and without (the control column). Quartz sand was chosen due to its inert properties. The analysis proves that iron forms a geochemical barrier and it has significant impact on the mode of the heavy metal $(\mathrm{Cu})$ migration in the soil.
\end{abstract}

Keywords: geochemical soil analysis, iron impact, migration of heavy metals in the soil.

\section{Introduction}

In various parts of Lithuania the polluters of soil are industry, transport, agriculture and military operations. The most polluted soil is detected in the largest cities where big industrial companies and the main highways are located. The concentrations of heavy metals, polyaromatic hydrocarbons, carbon monoxide, and nitric oxide as a rule are very high in such areas (Oškinis 1996).

Soil is important not only by its ecological functions (productivity of biomass, filtration of water, transformation of materials, etc.). City soils are very important in social and economic viewpoint (Taraškevičius and Šiaudinienè 2001)

Soils are often polluted with heavy metals. Increase of heavy metals concentration in soils is also noticed near motor highways with heavy traffic (Oškinis 1996). Most common health problems caused by heavy metals are the following: heart and vascular diseases, cancer and immunodeficiency.

Heavy metals distribution depends on relief, soil types and migration abilities of heavy metals. Pollution in soil is changing and new chemical combinations occur because of increasing variety of contaminants.

Heavy metals distribution and migration in soils mostly depends on geochemical soil characteristics and ways of their accesing to soil (Kadūnas 1998; Jankauskaitè et al. 2008).

Chemical barriers are among the most important factors limiting heavy metal migrations (Karol Reuben 2003; Zinkutè 2002).

Cities and towns serve as sources of technogenic substances for the heavy metal migration. Fate of pollutants in the urban environment depends on internal (chemical, toxicological) and external (geochemical conditions of migration, geochemical barriers, landscape conditions) factors (Kasimov, Lychagin 1998).

Copper and zinc concentrations usually are higher at the roadside. These elements are quite mobile. Migration is especially intensive in highly wet soils (Kadūnas 1998).

The composition of major elements in the Lithuanian topsoil has been thoroughly studied for determining agricultural and landscape characteristics. Recently the concentration of heavy metals in arable soils has also been studied.

Geochemical information can be used in agriculture, forestry, it is useful in epidemiological and other health studies, biologists and specialists from other branches of science can use the data on the distribution of microelements in environmental studies.

The main problem described is the continual growth of heavy metals concentration in the soils of big Lithuanian cities. As a case study the city of Klaipeda was chosen, as one of the biggest cities in Lithuania and the seaport with its gate to the Baltic Sea. On the basis of pollution evaluation research (Baltrènas and Vaišis 2006; Baltrènas et al. 2006) made before, heavy metal concentration anomalies were determined in the area nearby the harbour, the northern part of the city. High increase of $\mathrm{Co}, \mathrm{Cr}, \mathrm{Cu}$ and $\mathrm{Zn}$ concentrations was detected there. This phenomenon impels deeper analysis which has been an important topicality of this work.

Iron particles are emitted from ferroalloys during loading and unloading ships in the port. The aim of this work is to analyse the iron impact on heavy metal $(\mathrm{Cu})$ mobility in soils and find the best methodology to make the experiment. 
In the paper a simplified method is proposed for evaluation of iron impact on heavy metals mobility (in this case $\mathrm{Cu}$ ) without using complex extraction methods.

Chemical barriers are the most important factors which limit heavy metals migration in the soil. Heavy metals distribution and migration in soils mostly depends on geochemical soil characteristics and ways of their infiltration into soil (Kadūnas et al. 1999).

Heavy metals (HM) in the soil occur in various mobile and immobile forms: as free ions in soil solution, in exchangeable form, bound to organic matter, carbonates, Fe-Mn oxyhydroxides, sulphides and other primary and secondary soil minerals. Only a mobile HM can get from the soil into surface water and groundwater as well as into plants. Therefore, HM mobility and plant availability as well as environmental toxicity depend on their chemical origin and soil quality factors (Sabienè et al. 2004). Chemical elements, depending on their migration characteristics, are grouped into the ones migrating by air and water (Kadūnas 1998).

Below there are the migration types (Kadūnas 1998):

1. Mechanical migration described by laws of mechanics. This migration happens in solid state. It depends on the size of particles, wind flow speed, etc.

2. Physical-chemical migration described by physical-chemical laws like diffusion, sorption, dissolution and sedimentation. Migration in the form of ions occurs between colloidal particles or inside of colloids.

3. Biogenic migration. It is determined by the vital activity of live organisms.

4. Technological migration. It is determined by anthropogenic activity. Critical factors for this migration are extraction of chemical elements, transportation, etc.

According to the hypothesis, it is possible to reduce HM mobility and environmental toxicity by changing or properly modifying some quality factors of soil. That is why it could be important to investigate the influence of some soil quality factors on HM adsorption-desorption processes and their mobility in various soils (Sabiene et al. 2004; Ciccu et al. 2001).

The mobility of heavy metals in soils is influenced by several factors including $\mathrm{pH}$, sorption on minerals such as phyllosilicate clays and iron oxides, and conversion to inorganic or organic compounds (Neubauer et al. 2002).

Transformation of the properties and geochemical conditions of the soil are affected by the presence of technogenic substances in it. These substances have an influence on the geochemical conditions of chemical element migration in soils, such as $\mathrm{pH}$ and $\mathrm{Eh}$ values. These processes are mainly affected by macroelements $(\mathrm{Fe}, \mathrm{Ca}, \mathrm{Mg}$ ) and mineral acids. The elements themselves usually are not toxic for flora and fauna. But they affect the localization or destabilization of anomalies in urban soils. It is important to know that chemical elements behave quite differently, and the same anthropogenic agent may be a mobilizer in some cases and a stabilizer in other ones (Kasimov, Lychagin 1998).
In some geochemical classifications all the elements are subdivided into three groups according to their migration capacity in natural media:

- group 1 received a conventional name of cationogenic elements - elements that usually migrate in the cationic form $(\mathrm{Na}, \mathrm{K}, \mathrm{Ca}, \mathrm{Sr}, \mathrm{Ba})$;

-group 2 represents the complex-forming elements (hydrolysates). They migrate mainly as intricate complex compounds and have two maximums of solubility - in strong acid and strongly alkaline media;

- group 3 embraces anionogenic elements. They migrate mainly as ingredients of various complexes. These elements are very mobile in alkaline media and less mobile in acid ones.

Two basic urban transformation processes could be outlined. The first one is acidification (caused by release of sulphur and nitrogen), which has a mobilizing effect for cationogenic elements, especially heavy metals. For another group of elements, that are mobile in alkaline environment, acidification acts as a stabilizing agent fixating them in soils (Kasimov, Lychagin 1998).

From geochemical barriers aspect it could be estimated that alkaline barriers are more characteristic of cationogenic elements, whereas acid barriers are proper for the anionogenic ones.

High input of dust in towns leads to enrichment of soils with $\mathrm{Fe}$ and $\mathrm{CaCO}_{3}$. It slightly influences $\mathrm{pH}$ and $\mathrm{Eh}$ values of soils, but strongly affects formation of a geochemical barrier.

While investigating the mobility of HM in the soil and iron impact on the HM mobility, difficulties were encountered due to necessity of special techniques and laboratories for the analysis.

\section{Investigation object and methodology}

The main investigation object of the work is iron impact on heavy metal mobility.

The experiment was aimed at checking the impact of iron filings on the soil environment in Klaipeda port. Ferroalloys storing works were supposed to cause iron emission.

Most of heavy metals extraction methods can be marginally cost-effective and/or difficult to implement. We managed to find a simple and effective method with low cost and friendly to the environment.

Fig. 1 shows a scheme of the proposed experiment for the analysis of iron impact on HM mobility.

Copper $(\mathrm{Cu})$, as a heavy metal, was chosen for the experiment. The median concentration of $\mathrm{Cu}$ according to the previous investigation in Klaipeda Northern part was $26.1 \mathrm{mg} / \mathrm{kg}$ (Baltrènas and Vaišis 2006). According to geologists, migration mode helps to describe the mobility of heavy metals in the soil, and iron makes the migration of heavy metals slower. The experiment was made in order to check the statement.

Methodology of the experiment was the following:

1. First of all it is necessary to choose the volume of seasonal rainfall (e.g. in summer), to calculate the amount of rainfall to be passed through the experimental sand per day. A typical rainfall 
quantity of $20 \mathrm{~mm}$ was taken in the middle of summer in Klaipeda city (Lithuania).

2. The next step is calculation of the concentration. That was done with an assumption that $30 \%$ of $\mathrm{HM}$ in the soil are in mobile form, therefore, it will make $10 \mathrm{mg} / \mathrm{kg}$ concentration of $\mathrm{Cu}$ in mobile form (salts, alkalis) and the average moisture will be about $20 \%$. Heavy metals could be only in a water (dissolved) phase while mobile. Following the above assumptions the HM concentration in soil water will make about $50 \mathrm{mg} / \mathrm{l}$ (10/0.2). The maximum concentration of copper was calculated by dividing it by the water quantity in the soil: $\underline{C o n c}(\max )=66(\mathrm{mg} / \mathrm{kg}) /$ $0.2=330 \mathrm{mg} / \mathrm{l}$. After the analysis of prepared mixtures the concentrations of solutions were $65.9 \mathrm{mg} / \mathrm{l}$ and $232.1 \mathrm{mg} / \mathrm{l}$ of copper salt. The quality of salt used for the experiment was the reason of such a result.

3. The experimental sand of $7.5 \mathrm{~cm}$ thickness was chosen, as it had been chosen in the previous investigation (Baltrènas and Vaišis 2006). The ph was chosen by its natural value in the soil of the analysed area.

4. Similar concentrations had been chosen in other works (Brannvall and Kazlauskienè 2005).

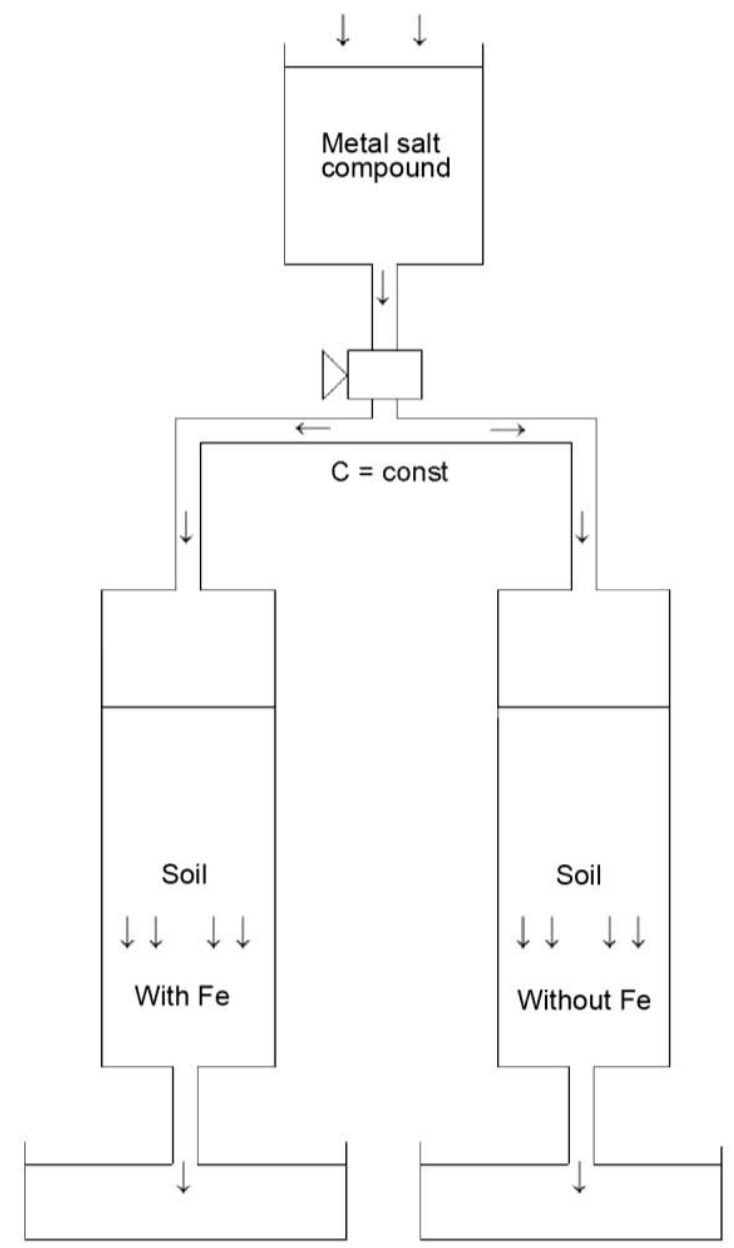

Fig. 1. Scheme of the experiment of iron impact on heavy metals migration in the soil

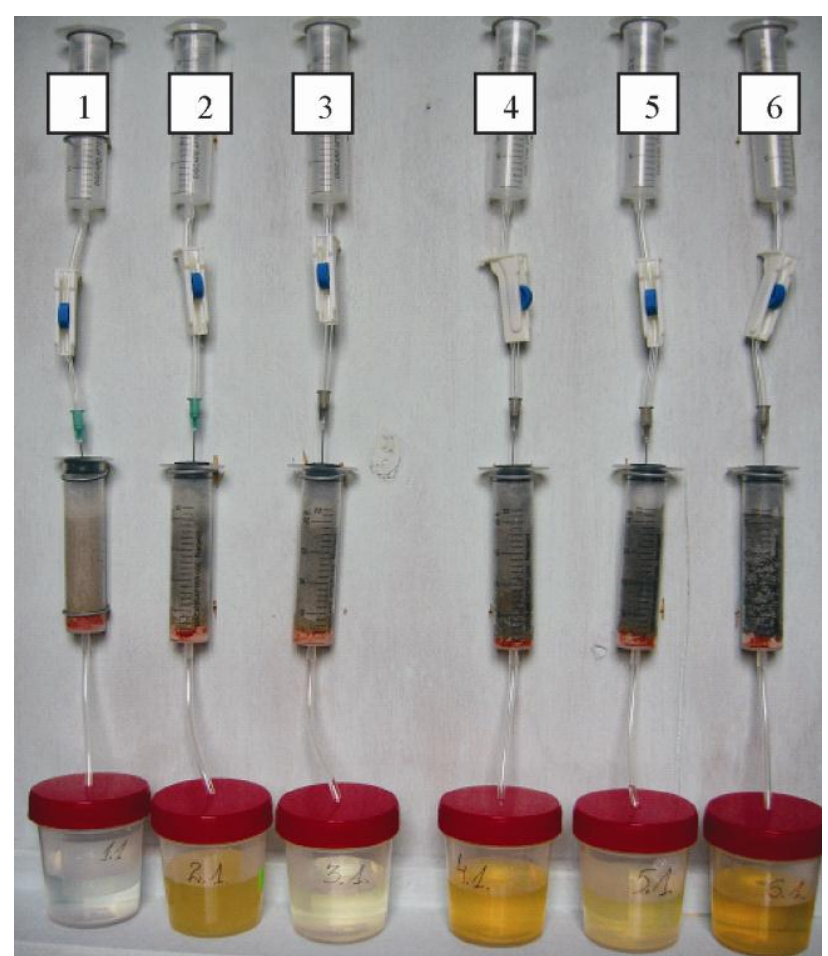

Fig. 2. Experimental board after the first day of the analysis of iron impact on heavy metals mobility in sand

5. Quartz sand was used for the experiment due to its inert properties. Before analysis the quartz sand was washed with distilled water. Iron filings were used for preparation of 1.5 and $10 \%$ iron-sand mixtures.

This experiment lasted for 9 days. The total number of specimens per day was 12 . About $240 \mathrm{ml}$ of copper salt solution $\left(\mathrm{CuNO}_{3}\right)_{2}$ was passsed.

A special wooden board with six columns was constructed. Medical syringes served as columns. They were fixed on the experiment stand. Special cruets with the capacity of $60 \mathrm{ml}$ were used for collecting the experimental solution. In Fig. 2 the experimental stand is presented.

The experiment was accomplished in the following way: the copper salt solution of $65.9 \mathrm{mg} / \mathrm{l}$ concentration was poured into columns 1, 2, 4 and 6 , while the copper salt solution of $232.1 \mathrm{mg} / \mathrm{l}$ concentration was poured into columns 3 and 5. Column 1 contained quartz sand without iron filings, columns 2 and 3 were filled with quartz sand containing $1 \%$ of iron filings, columns 4 and 5 - with $5 \%$ of iron filings and column 6 contained $10 \%$ of iron filings in its quartz sand. Each cruet was marked with an appropriate number.

\section{Results and discussion}

The samples were taken after the third day of the experiment. The main target of the experiment was to avoid outside factors which could occur during the filtration process - a steep ground, chemical reactions of salts and primary adsorptions.

$\mathrm{Cu}$ concentration, which remained after filtration through the control sand with no Fe particles, was quite 
low at the start of the experiment. The estimated concentrations were 23.86 and $93.5 \mathrm{mg} / \mathrm{l}$ (providing solution concentration of 65.9 and $232.1 \mathrm{mg} / \mathrm{l}$ ) after the third day of the experiment (see Fig. 3).

At the beginning of the experiment the adsorption at the quartz sand particles surface was intensive because there were no other geochemical barriers in the experimental sand.

The concentration was gradually getting higher and on the ninth day of the experiment nearly reached the feed concentration of the solution. This shows that the sand was fully filled and the ability of adsorption was entirely used.
It could be considered that in the circumstances of this experiment nine days were enough for adsorption elimination from the sand.

In all the variants of the experiment $\mathrm{Cu}$ concentrations were significantly lower exactly after filtration through the soil with iron particles in comparison to the one without iron particles.

This is an evidence that iron particles form a geochemical barrier.

$\mathrm{Cu}$ concentration was gradually increasing in sand with $1 \%$ of iron filings and at the end of the experiment it reached $9.1 \mathrm{mg} / l$ (it is $13.8 \%$ from feed concentration of $65.9 \mathrm{mg} / \mathrm{l}$, see Fig. 4), and $81.0 \mathrm{mg} / \mathrm{l}$ (it is $34.9 \%$ from feed concentration of $232 \mathrm{mg} / \mathrm{l}$, see Fig. 5).

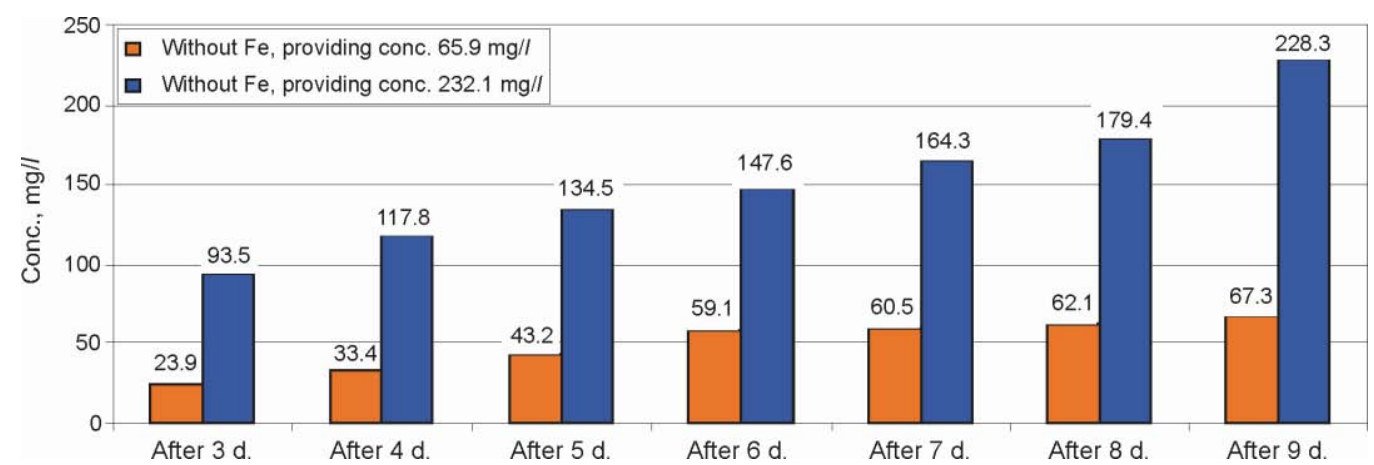

Fig. 3. Variations of $\mathrm{Cu}$ salt concentration during the period of the experiment. Solution was passed through sand without iron filings providing initial concentrations of 65.9 and $232.1 \mathrm{mg} / \mathrm{l}$

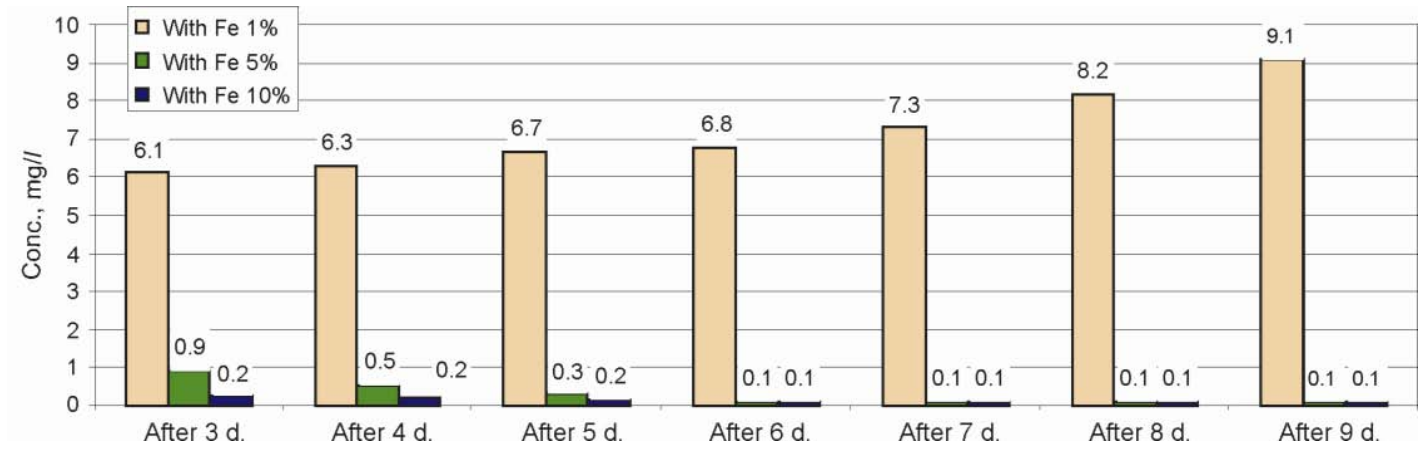

Fig. 4. $\mathrm{Cu}$ salt concentration variations during experiment period. Solution of $65.9 \mathrm{mg} / \mathrm{l}$ concentration was passed through sand with different quantity of iron particles

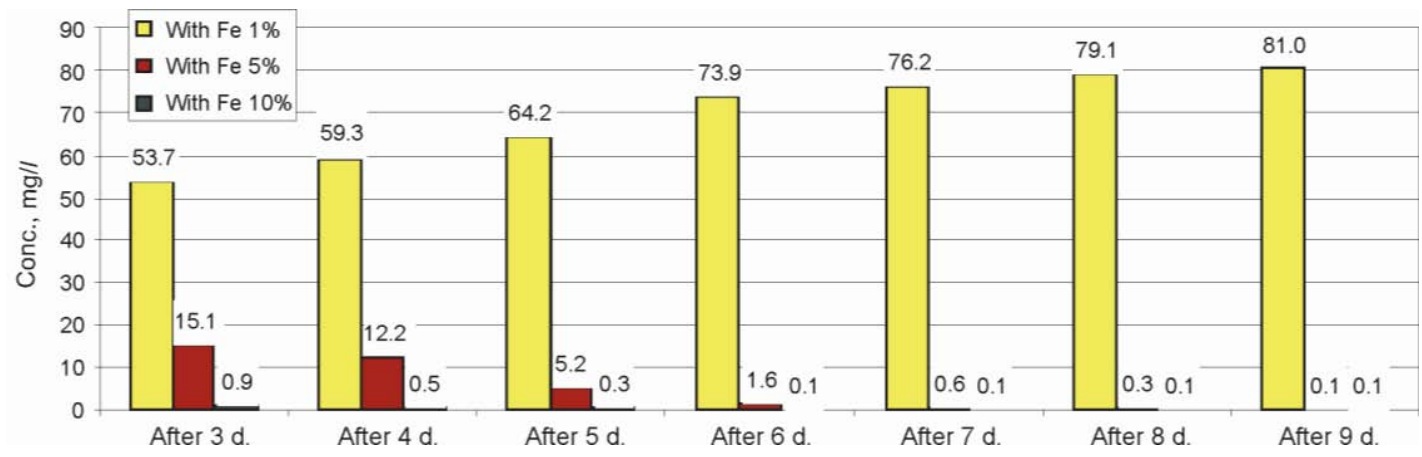

Fig. 5. Cu salt concentration variations during the experiment. Solution of $232.1 \mathrm{mg} / \mathrm{l}$ concentration was passed through sand with different quantity of iron particles 
It must be noted that the solution of a higher concentration faster saturates the sand by adsorption. That is why at the beginning of the experiment the higher $\mathrm{Cu}$ solution part reacts with iron filings, while the residual $\mathrm{Cu}$ concentration (not reacted) is outflowing.

This shows that the feed concentration of the solution has an impact on the residual concentration (for the solution with higher concentration, the residual concentration was also higher).

Different percentage of iron particles in the quartz sand showed that $\mathrm{Cu}$ concentration in specimens after filtration had double character of variation (see Fig. 4 and 5 ). The feeding was noticed in both the solutions of $65.9 \mathrm{mg} / \mathrm{l}$, and $232.1 \mathrm{mg} / \mathrm{l}$ concentration. The variation character is different by iron particle percentage in the quartz sand. In the case of $1 \%$ of iron filings, the concentrations were increasing after filtration within the period of experiment, and an opposite tendency was noticed in the sand with 5 and $10 \%$ of iron filings - the concentration was continually decreasing. This shows an excess quantity of iron filings in the sand which can react with $\mathrm{Cu}$ solution. Therefore, for implementing such a kind of experiment it is advisable to use either a small quantity of iron filings in the sand (up to $1 \%$ ) or extend the period of the experiment.

\section{Conclusions}

1. The residual $\mathrm{Cu}$ concentration as a result of filtration through the quartz sand without Fe filings (control column) was gradually increasing within the period of the experiment. On the ninth day of the experiment it was already near the feed solution concentration. This shows that the sand was fully filled and the ability of adsorption was entirely used during the period.

2 . In all the variants of the experiment $\mathrm{Cu}$ concentrations were significantly lower exactly after filtration through the sand with iron particles in comparison with the telltale sand without iron particles. It is evident that iron particles form a geochemical barrier.

3 . In the sand with $1 \%$ of iron particles $\mathrm{Cu}$ concentration was gradually increasing, and at the end of the experiment reached $9.1 \mathrm{mg} / \mathrm{l}$ (it is $13.8 \%$ from feed concentration of $65.9 \mathrm{mg} / \mathrm{l}$ ), and $81.0 \mathrm{mg} / \mathrm{l}$ (it is $34.9 \%$ from feeded concentration of $232.1 \mathrm{mg} / l$ ). This shows that feed concentration of the solution has an impact on the residual concentration.

4. In the sand with 5 and $10 \%$ of iron particles the concentrationn during the experiment was continually decreasing. This shows an excess quantity of iron particles in the sand which can react with the $\mathrm{Cu}$ solution.

5. Iron particles are emitted from ferroalloys during loading and unloading ships in the port. Fe makes the migration slower, so the heavy metals concentrate in the sand.

\section{References}

Baltrėnas, P.; Vaišis, V. 2006. Klaipedos miesto šiaurinès dalies dirvožemio užterštumo sunkiaisiais metalais tyrimai [Research into soil contamination by heavy metals in the northern part of the Klaipeda city, Lithuania], Geologija. Vilnius: Lietuvos mokslų akademijos leidykla, 1-7.

Baltrènas, P.; Fröhner, M.; Kvasauskas, M. 2006. Influence of stevedoring operations of liquid and powdery fertilizers at Klaipeda state seaport on the ambient air quality, Journal of Environmental Engineering and Landscape Management 14(2): 59-68.

Brannvall, E.; Kazlauskienè, A. 2005. Experimental research on sorption of $\mathrm{Pb}^{2+}, \mathrm{Zn}^{2+}, \mathrm{Cu}^{2+}, \mathrm{Mn}^{2+}, \mathrm{Ni}^{2+}, \mathrm{Na}^{+}, \mathrm{Ca}^{2+}$ and $\mathrm{Cl}^{-}$ from solutions on clinoptilolite, in The $6^{\text {th }}$ International Conference "Environmentall Engineering": selected papers. May 26-27, 2005. Vilnius Gediminas Technical University. Vilnius: Technika, 1: 49-53.

Ciccu, R.; Ghiani, M.; Peretti, R.; Serci, A.; Zucca, A. 2001. Heavy metal immobilization using fly ash in soils contaminated by mine activity. University of Cagliari, Italy.

Jankauskaitè, M.; Taraškevičius, R.; Zinkutè, R.; Veteikis, D. 2008. Relationship between landscape self-regulation potential and topsoil additive contamination by trace elements in Vilnius city, Journal of Environmental Engineering and Landscape Management 16(1): 5-14. doi:10.3846/1648-6897.2008.16.5-14

Kadūnas, V.; Budavičius, R.; Gregorauskienè, V.; Katinas, V.; Kliaugienè, E.; Radzevičius, A.; Taraškevičius, R. 1999. Geochemical Atlas of Lithuania. Geological Institute. Vilnius. 72 p., 18 tables, 240 maps.

Kadūnas, V. 1998. Technogenine geochemija [Technogenical geochemistry]. Vilnius: Geologijos Institutas. $145 \mathrm{p}$.

Kasimov, N.; Lychagin, M. 1998. Heavy metals in urban soils in Russia [cited 19 January 2009]. Available from Internet: <http://natres.psu.ac.th/Link/SoilCongress/bdd/ symp28/771-t.pdf>.

Neubauer, U.; Furrer, G.; Schulin, R. 2002. Heavy metal sorption on soil minerals affected by the siderophore desferrioxamine $B$ : the role of $\mathrm{Fe}$ (III) (hydr)oxides and dissolved Fe (III). Swiss Federal Institute of Technology (ETH). Zurich, Switzerland.

Oškinis, V. 1996. Dirvožemio ir biotos apsauga [Soil and biota protection]. Vilnius: Technika. $53 \mathrm{p}$.

Reuben, K. H. 2003. Chemical grouting and soil stabilization. New York: Marcel Dekker, 2003. New scientist, danger of toxic metals in soils underestimated [cited 12 December 2003]. Available from Internet: <www.newscientist.com>.

Sabienè, N.; Brazauskienė, D.; Rimmer David, M. 2004. Sunkiųjų metalų judriųjų formų nustatymas ịvairiais ekstrahavimo metodais [Determination of heavy metals migration forms by different extraction methods], Ekologija 1: 36-41.

Taraškevičius, R.; Šiaudinienè, A. 2001. Pedogeochemical accumulating and paragenetic associations in the industrial area of Žirmūnai district in Vilnius, Aplinkos inžinerija [Environmental Engineering] 9(3): 176-183.

Zinkutè, R. 2002. Trace element technogeneus associations in topsoil of urban territories of Lithuania. Vilnius: Institute of Geology and Geography. 200 p. 


\section{EKSPERIMENTINIS GELEŽIES ĮTAKOS SUNKIŲJŲ METALŲ (VARIO) MIGRACIJAI DIRVOŽEMYJE TYRIMAS}

V. Vaišis, L. Šuksta

Santrauka

Straipsnyje analizuojama geležies dalelių įtaka sunkiųjų metalų migravimui šiaurinèje Klaipėdos uosto dalyje. Klaipėda pasirinkta, nes tai tranzitinis uostas, kuriame vyksta krovinių krovimas, laivų statyba, rekonstravimas ir visos kitos funkcijos, susijusios su jūrine veikla ir krovininių laivų paslaugomis. Kaip ir kiekvienoje ekosistemoje dirvožemiams būdingos akumuliacinès savybès, juose kaupiasi ịvairios medžiagos, kartu - ir teršalai. Geležies ịtakai sunkiujų metalų migravimui tirti buvo sukonstruotas specialus eksperimentinis stendas su šešiomis kolonomis, pro kurias per tiriamą terpę - kvarcinị smèli (nes jis yra inertiškas) buvo leidžiamas vario druskos tirpalas. Eksperimente naudotas kvarcinis smëlis su geležies drožlèmis $(1,5$ ir $10 \%)$ ir be jų (kontrolinis). Iš analizès rezultatų akivaizdu, kad geležis turi reikšmingą įtaką sunkiojo metalo $(\mathrm{Cu})$ migracijos pobūdžiui dirvožemyje bei sukuria geocheminį barjerą

Reikšminiai žodžiai: geocheminė dirvožemio analizè, geležies įtaka, sunkiųjų metalų migravimas dirvožemyje.

\section{ЭКСПЕРИМЕНТАЛЬНОЕ ИССЛЕДОВАНИЕ ВЛИЯНИЯ ЖЕЛЕЗА НА МИГРАЦИЮ ТЯЖЕЛЫХ МЕТАЛЛОВ (МЕДИ) В ПОЧВЕ}

\section{В. Вайшис, Л. Шукста}

\section{Резюме}

Клайпеда - крупный транзитный порт, в котором погрузкой грузов, строительством кораблей и их реконструкцией, а также всеми остальными функциями, касающимися морской деятельности и услуг грузоподъемных кораблей, занимаются 19 больших компаний. Как и каждая экосистема, почва функционирует как накопитель и резервуар материалов, включая и загрязняющие вещества. В статье главное внимание уделено исследованию частиц железа, оказывающих влияние на миграцию тяжелых металлов в северной части города Клайпеды около Клайпедского порта. С этой целью была сконструирована специальная доска с шестью колоннами, через которые в анализируемую среду - кварцевый песок (инертный материал) - пропускался раствор. Для эксперимента был выбран кварцевый песок со стружками железа (1, 5 и 10\%) и без него. Результаты анализа показали, что железо оказывает значительное влияние на формы миграции тяжелого металла (меди), а также создает геохимический барьер.

Ключевые слова: геохимический анализ почвы, влияние железа, тяжелые металлы, миграция тяжелых металлов в почве.

Vaidotas VAIŠIS. Doctor of Technological Sciences, Dept of Environmental Protection, Vilnius Gediminas Technical University (VGTU).

Master of Science (environmental engineering), VGTU, 2001. Bachelor of Science (environmental engineering), VGTU, 1999. Publications: author of 15 scientific publications. Research interests: environmental protection, sorbents of oil products, noise prevention, soil contamination, waste management.

Lidija ŠUKSTA. Master, Dept of Environmental Protection, Vilnius Gediminas Technical University (VGTU).

Master of Science (environmental engineering), 2007. Bachelor of Science (environmental engineering), VGTU, 2005. Publications: author of 2 scientific publications. Research interests: environmental protection, heavy metals, soil contamination. 